Adherents.com. Access: www.adherents. $\mathrm{com} /$.

Adherents.com is a collection of more than 41,000 "adherent statistics and religious geography citations." Adherents.com has no specific affiliation and claims to be the second most frequently visited general religion site on the Internet. The site is the brainchild of Preston Hunter, a computer programmer in Texas. Its target audience is "anybody who desires statistical information about the size or spread of a faith group or wants a general idea of the religious make up of a specific country, continent, state or province."

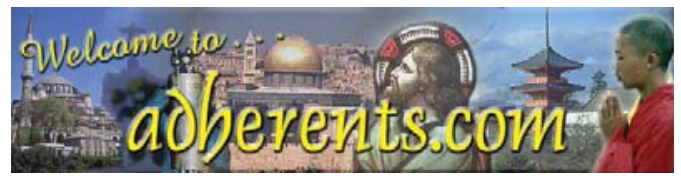

The homepage contains summary statistics of the world's major religions, the major branches of these religions, and a list of the largest religious groups in the United States. Within Islam, for example, 940 million Muslims are Sunni, while 120 million are Shiites. Also on this page are links to the religious affiliation of U.S. Presidents, Vice Presidents, Supreme Court Justices, members of Congress, and state governors.

Two disclaimers, taken from Adherents. com's homepage, must be kept in mind when navigating this site: Adherents.com incorporates statistics from several, sometimes contradictory, sources (often listed side-by-side), and the statistics provided on the site are not exhaustive. A visit to Adherents.com suggests a further caveat: the site itself needs maintenance. The link "Congressional Religious Affiliation" dates from 2000 and, of course, we have had a general election since then. Additionally, Adherents.com contains a number of broken and out-of-date Internet links.

Joni R. Roberts is associate university librarian for public services and collection development at Willamette University, e-mail: jroberts@willamette.edu, and Carol A. Drost is associate university librarian for technical services at Willamette University, e-mail: cdrost@willamette.edu
The homepage also provides two handy indexes: "Religion by Location" and "Religion by Name." Each index provides a comprehensive, alphabetical listing of religious statistics. For instance, in the first index, we learn that 26 percent of Minnesotans are Lutheran. In the second index, we can find the number of Presbyterian churches and/or members in any particular state in the nation. Unfortunately, in the same index, we find no such state-bystate breakdown for the Lutheran Church in America, this country's largest Lutheran body. Such information is provided, however, for the Lutheran Church, Missouri Synod.

Bottom line: check Adherence.com for religious statistics, but be prepared to search further for up-to-date data.-Wendell Johnson, Waubonsee Community College, WJohnson@waubonsee.edu

\section{Civil Rights in Mississippi Digital Archive.}

Access: www.lib.usm.edu/ spcol/crda/.

In the midst of the Civil Rights Movement, large numbers of activists traveled throughout the southern United States marching to integrate public institutions, as well as educating and registering voters. Many of the volunteers concentrated reform efforts in Mississippi, where segregation was deeply ingrained and institutionalized.

During Freedom Summer 1964, recruits organized activities in local schools and community centers, expanded voter registration efforts, and worked towards establishing a political party to challenge the whites-only status quo. The largest site for Freedom Summer events was Hattiesburg, home of the University of Southern Mississippi (USM). Thanks to a generous Institute of Museum and Library Services federal grant, students and researchers can now return to Hattiesburg and the turbulence of those times through a digital archive established by the USM Libraries.

The collection currently includes letters, diaries, pamphlets, photographs, oral histories, and audio transcripts that focus on events that occurred in Mississippi during the Civil Rights Movement and Freedom Summer. The 
wealth of the archive is to be found in its extensive oral history and image files. The site contains lengthy interviews with major figures such as Charles Evers, Fannie Lou Hamer and Mississippi Governor Ross Barnett, as well as interviews with local residents and northern Freedom Riders. High-quality digitized photographs and other images are fully searchable through the USM Libraries catalog and the Web site database.

In addition to original source documents from the period, a brief essay and timeline giving a historical context to the period are provided, as is a link to other relevant resources. The site also contains intellectual property rights and permissions information as well as preservation and digitization guidelines.

While the content of the archive is of great interest, the site itself appears to be in need of some updating and maintenance. Some audio-enhanced transcripts and picture files contain errors that prevent downloading. While search features work well, navigation through the site and away from the USM Libraries catalog could be improved. Finally, although messages on the "Manuscripts and Photographs" page indicate that more digitized materials are forthcoming, it appears that many of the pages have not recently been modified. Visitors to the digital archives will find here a fascinating collection of artifacts from a momentous period in U.S. history but will leave wishing for more.-Linda Frederiksen, Washington State University, Vancouver, frederik@vancouver.wsu.edu

The National Agricultural Law Center. $A c$ cess: www.nationalAgLawCenter.org.

If you are researching farm commodity programs or landowner liability, international agricultural law or the National Organic Program, this is the Web site for you. The National Agricultural Law Center (NALC) is based at University of Arkansas School of Law and is funded through the National Agricultural Library of the USDA Agricultural Research Service.

Its mission is to provide online research tools in the fields of agricultural and food law. The NALC's staff includes law and research professors, lawyers, research fellows, as well as other specialists in the field.

The NALC's site was recently reorganized and has an attractive look. Clearly labeled links

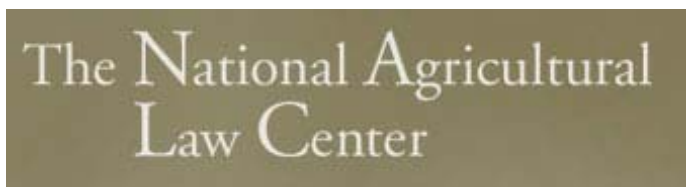

at the top of most pages ensure easy navigation. The addition of some brief instructions for searching would be helpful. There are no search tools on the site, so it is necessary to investigate the different links in order to find the hidden research gems.

The 27 new "Reading Rooms" each focus on a particular aspect of agricultural law, such as biotechnology, country of origin labeling, food safety, and pesticides. Within each "room" users will find an essay that gives an overview of the topic as well as extensive links to federal regulations, statutes, case law, government publications, research publications published by NALC, and links to other resources. Ten more rooms are under construction. NALC research publications are also cross-referenced under "Research Publications."

NALC publishes an electronic newsletter with case summaries, a "Federal Register Digest," and USDA judicial officer decisions. The newsletter is available through the Web site with archives back to 2002. Other resources include the impressive "Agricultural Law Bibliography," which is updated quarterly and is searchable using keywords. The extensive source list is up-to-date and easy to use.

Users may also access Web sites of Senate and House committees and subcommittees as well as General Accounting Office and Congressional Research Service reports through "Congressional Links." "Reference Desk" provides links to other bibliographies, glossaries, journals, associations, and online research guides, but not all of the links work.

Overall, the site is an excellent resource for a specialized field. Graduate and advanced undergraduate students and researchers in the fields of agricultural and food law should find it a valuable resource, even though the site makes its users earn its rewards. Because there are no search features on the site, with the exception of the aforementioned "Agricultural Law Bibliography," users must be willing to investigate all of the nooks and crannies by exploring all of the links. The patient researcher will be rewarded with a wealth of information.-Ann Flower, Monterey Institute of International Studies, a ower@miis.edu 